quite appreciable sparks during the period of activity. The charges took fifteen or twenty seconds to build up after discharge, and the experiment was repeated very frequently.

The second thundercloud produced two peals of thunder and a slight shower, soon after which the abnormal electrical conditions ceased to manifest themselves, about three-quarters of an hour after they were first noticed. R. A. Watson WatT.

Meteorological Office, South Farnborough, Hants, April ${ }_{5}$.

\section{The Influence of Tides on Wells.}

RefERRING to Mr. Jas. Kewley's letter in Nature of April 13, it is not unusual for the water in wells to rise and fall with the tides when such wells are near the sea. But is it necessary to assume that the phenomenon is due to the weight of the incoming tide compressing the underlying strata, as suggested by Mr. Kewley? Surely it may be sufficiently explained on the assumption that as the rising tide is a rising head of water it, without necessarily compressing the rocks beneath, tends to compress the air and replace the less dense fresh water included in the interstices and fissures, thus affecting the water-level of any contiguous well. In this connection may I direct attention to a letter of mine on "Tidal Action of the Earth's Crust," published in the English Mechanic, June II, Igog? Cecil Carus-Wilson.

\section{PHYSIOLOGY IN THE WORKSHOP.}

I $N$ the never-ending struggle between capital $I$ and labour, or rather between employers and workmen, the points of dispute have been largely concerned with the hours of labour and wages, the employers trying to obtain as long hours for as low wages as possible, while labour has struck for a shortening of hours with increased wages. Labour is thus regarded as a commodity, to be bought as cheaply and sold as dearly as possible.

In most of these disputes it would seem that both sides have lost sight of the fundamental conditions of their own prosperity. It is, after all, of little account to the employer that he should be able to buy cheaply so many hours of other men's lives. 'The only factor which really concerns him is that he should be able to produce as large a quantity of his goods as possible at as small a price as possible, reckoning both rent of capital and cost of labour. An implicit assumption seems always to be made that the more hours of a man's life the employer can buy for a certain sum, the cheaper will be his cost of production. But labour also is concerned in the cost of output. It is a truism that when business is slack, i.e. when the profits are small, strikes are few and far between, the workers recognising that it would be better in many cases to close down works than to give them increased wages. Both employers and workmen are therefore concerned that the industry in which they are engaged should be as prosperous as possible, i.e. that production should be as cheap and rapid as possible. To this end both parties should co-operate. The only divergence of view which is reasonable should occur later when the question arises of the division of the profits, i.e. as to how much NO. 2425 , VOL. 977 should be assigned to labour and how much for management and rent of capital.

Both sides are therefore interested in the efficiency of labour and its use to the best possible advantage-the employer in order that he may obtain as great a production at as small a price as possible; the workman that he may be able to earn enough to keep himself in comfort, while allowing some time in the day or week for recreation and the enjoyment of life.

It is remarkable how little attention has been paid in this country to the problem of how to use labour to the best possible advantage. The appearance of a Memorandum on "Industrial Fatigue and its Causes" (Cd. 8213 , Wyman and Sons, Ltd., price $\mathrm{I} \frac{1}{2} d$.), which has been drawn up and issued by the Health of Munition Workers Committee, is therefore of extreme importance at the present time, since its object is to point out the only method by which increased efficiency of production can be attained.

In this pamphlet it is shown that the problem of scientific industrial management is fundamentally a problem in industrial fatigue. For the continued efficiency of an animal or man, rest must alternate with work, and the periods of rest and work must vary with the type of work involved. This elementary principle is acted upon generally in our management of horses. The report is a plea for its application also to the case of man. We cannot get the utmost possible work out of man or horse unless this principle is taken into account. We have thus to determine in the case of man what are the maximal efficiency rhythms for various types of work and workers. For work in which severe muscular effort is required it seems probable that the maximal output over a day's work and the best conditions for the wurkers' comfort and maintained health will be secured by giving short spells of strenuous activity broken by longer spells of rest, the relative amount of time devoted to resting being greater than in employments in which nervous activity is more prominent or more complicated.

The truth of this statement is well illustrated by an anecdote recorded in the Memorandum before us. Two officers at the front competed in making equal lengths of a certain trench each with an equal squad of men. One allowed his men to work as they pleased but as hard as possible. The other divided his men into three set: to work in rotation, each set digging their hardest for five minutes only, and then resting for ten until their turn came to dig again. The latter team won easily. Another instance is that of a munitions factory, where men engaged in the severe work of moulding were required to rest fifteen minutes in every hour of work. The men objected to this long spell of rest in each hour because the work was piecework, so that the manager had to make the hourly rest compulsory and appoint a foreman to see that the regulation was complied with. As a result of this the output per hour was found to be actually increased.

It is evident that the optimum working rhythm for each kind of work can only be determined by 